\title{
Pengembangan Literasi Dini melalui Kerjasama Keluarga dan Sekolah di Taman Anak Sanggar Anak Alam Yogyakarta
}

\author{
Sjafiatul Mardliyah ${ }^{\varpi_{1}}$, Hotman Siahaan ${ }^{2}$, Tuti Budirahayu ${ }^{3}$ \\ Sosiologi, Universitas Airlangga Surabaya \\ DOI: $10.31004 /$ obsesi.v4i2.476
}

\begin{abstract}
Abstrak
Literasi dini adalah kemampuan anak usia dini untuk membaca, menulis dan berhitung. Literasi anak usia dini berkembang dan diperoleh di rumah maupun lingkungan sosialnya. Pentingnya literasi di era digital bagi anak usia dini menuntut perhatian serius. Penelitian ini bertujuan untuk menjelaskan pola pengembangan literasi bagi anak usia dini. Metode penelitian yang digunakan adalah pendekatan kualitatif. Data bersifat deskriptif berupa katakata tertulis dari informan yaitu fasilitator, orangtua siswa, kepala sekolah serta perilaku yang dapat diamati. Hasil penelitian menunjukkan bahwa literasi dini dengan memproduksi buku cerita berdampak mendorong percepatan perkembangan bahasa bagi anak usia dini. Modal sosial sebagai elemen pokok dalam pengembangan literasi dini berhubungan dengan kerjasama dalam menjalin komunikasi, memberi dukungan serta keteladanan dari orang tua dan fasilitator untuk menciptakan lingkungan belajar. Kondisi ini menghadirkan parenting di sekolah yang terpadu dengan proses pembelajaran secara alami dan bukan kegiatan yang diselenggarakan secara terbatas pada setiap semester yang bersifat monoton.
\end{abstract}

Kata Kunci: literasi; parenting; anak usia dini.

\begin{abstract}
Early literacy is the ability of early childhood to read, write and count. Early childhood literacy develops and is obtained in the home and social environment. The importance of literacy in the digital age for early childhood demands serious attention and is not light work. This study aims to explain the pattern of literacy development for early childhood. The research method used is a qualitative approach that has natural characteristics. The data is descriptive in the form of written words from the informant namely the facilitator, parents of students, the principal, and observable behavior. The results showed that early literacy by producing storybooks had the effect of encouraging accelerated language development for early childhood. Supporting factors are social capital as a key element in the development of education. Social capital is associated with cooperation in establishing communication, providing support and example from parents and facilitators to create a learning environment. This condition presents parenting in schools as a process that is integrated with the learning process naturally and is not a special activity that is held limited to each semester which is monotonous.
\end{abstract}

Keywords: literacy; parenting; early childhood

Copyright (c) 2020 Sjafiatul Mardliyah, Hotman Siahaan, Tuti Budirahayu

$\triangle$ Corresponding author :

Email Address : sjafiatul.mardliyah.os-2015@fisip.unair.ac.id (Graha Sunan Ampel Wiyung Surabaya)

Received 23 February 2020, Accepted 2 March 2020, Published 6 March 2020 


\section{PENDAHULUAN}

Literasi pada usia dini membutuhkan perhatian serius dari orangtua dan guru. Kemampuan literasi dini tidak terbatas pada kemampuan kognitif saja tetapi merupakan kegiatan sosial-psiko-linguistik yang kompleks dan berpengaruh pada aspek sosial dan kontekstual yang menjadi bagian integral perkembangan anak (McLachlan \& Arrow ,2017). Akan tetapi, jika proses belajar yang berlangsung berupa pemberian materi atau penjejalan, karena menurut orang dewasa dianggap penting dan harus diketahui anak, maka hal ini berlawanan dengan kondisi psikologis anak usia dini. Surat edaran nomor: 1839/C.C2/TU/2009 Departemen Pendidikan Nasional Direktorat Jenderal Manajemen Pendidikan Dasar dan Menengah menjelaskan Perihal Penyelenggaraan Pendidikan Taman Kanak-Kanak dan Penerimaan Siswa Baru Sekolah Dasar menegaskan bahwa prinsip pelaksanaan pendidikan TK menganut "Bermain sambil Belajar dan Belajar seraya Bermain". Pengenalan membaca, menulis dan berhitung (calistung) dilakukan melalui pendekatan yang sesuai dengan tahap perkembangan anak. Oleh karena itu pendidikan di TK tidak diperkenankan mengajarkan materi calistung secara langsung sebagai pembelajaran sendirisendiri (fragmented) kepada anak-anak. Konteks pembelajaran calistung di TK hendaknya dilakukan dalam kerangka pengembangan seluruh aspek tumbuh kembang anak, dilakukan melalui pendekatan bermain, dan disesuaikan dengan tugas perkembangan anak. Menciptakan lingkungan yang kaya dengan "keaksaraan" akan lebih mamacu kesiapan anak untuk memulai kegiatan calistung (Direktorat Jenderal, 2009).

Era revolusi industri 4.0 menjadikan anak usia dini tidak bisa lepas dari pengaruh tehnologi terutama penggunaan gadget (Barton, 2012). Artinya, bahwa jika anak sejak usia dini sudah bisa baca-tulis maka dia akan semakin cepat mempelajari lingkungannya. Oleh karena itu, upaya untuk mengembangkan literasi dini menjadi kebutuhan mendesak. Hal ini menuntut strategi untuk mempercepat kemampuan literasi anak usia dini.

Literasi anak usia dini dapat berkembang dan diperoleh di rumah maupun lingkungan sosialnya. Keberhasilan pendidikan anak usia dini memerlukan dukungan keluarga dan ketelibatannya dalam kegiatan di sekolah (Ulfah, 2020). Peran orang tua dan guru untuk menciptakan sistem ekologi belajar yang meliputi microsystem, mesosystems, exosyistem, dan macrosystem menjadi penting (Sheridan, Knoche, \& White, 2019). The Home Literacy Environment (HLE) atau lingkungan literasi keluarga terkait erat dengan minat baca anak usia dini. Lingkungan ini menuntut orang tua terlibat aktif mendukung anak dalam membaca dan menulis sejak dini (Yeo, Ong, \& Ng, 2014). Dengan demikian, kemampuan literasi awal anak usia dini ditentukan oleh dukungan orang tua dalam mengembangkan motorik halus melalui aktivitas menggambar dan menulis.

Sementara itu, lingkungan sekolah dan keterampilan guru dalam mengidentifikasi karakteristik anak sangat berkontribusi pada praktek pembelajaran guru di kelas. Guru dituntut mampu memahami bahwa setiap anak memiliki gaya belajar yang berbeda dan dipengaruhi oleh lingkungan sosialnya (Schachter R. E., 2017). Kemampuan guru dalam menguasai strategi pembelajaran membaca sangat menentukan keberhasilan proses pembelajaran literasi pada kelas anak usia dini. (Koch \& Sporer, 2017). Dalam hal ini menuntut kerjasama antara guru dan orang tua secara komunikatif. Kerjasama ini sangat penting, karena interaksi antara guru dan orangtua membantu menciptakan situasi belajar yang optimal (Teepe R. C., Molenaar, Oostdam, Fukkink, \& Verhoeven, 2019).

Peneliti menemukan fenomena menarik tentang literasi dini pada Taman Anak di Sanggar Anak Alam (Salam) Yogyakarta. Beberapa keunikan yang ada di Taman Anak Salam ini diantaranya adalah para siswanya tidak memakai seragam karena mereka menganggap bahwa seragam itu mahal dan mudah kotor. Mata pelajaran tidak dimunculkan terpisah, tetapi terintegrasi dalam proses belajar yang disebut daur belajar, yang menempatkan peserta didik sebagai subyek. Sistem evaluasi belajar diselenggarakan melalui portofolio dan bersifat non test. Guru di Salam sebagai fasilitator yang menjadi 
penghubung antara peran keluarga dan siswa. Fasilitator di Salam bisa berasal dari orang tua, relawan, maupun mahasiswa yang sedang magang.

Penelitian ini menggambarkan proses pembelajaran pada Taman Anak Salam melalui proses produksi buku cerita yang dilakukan oleh orang tua, guru, dan anak usia dini. Dengan demikian ditemukan gambaran pola pengembangan literasi yang efektif dan humanis bagi anak usia dini.

\section{METODOLOGI}

Penelitian ini dilaksanakan di Taman Anak Sanggar Anak Alam (Salam) di Yogyakarta. Metode penelitian yang digunakan adalah pendekatan kualitatif yang memiliki karakteristik alami (Natural Setting) sebagai sumber data langsung dan bersifat deskriptif berupa kata-kata tertulis atau lisan dari orang-orang dan perilaku yang dapat diamati. Pengumpulan data penelitian diperoleh melalui wawancara tidak berstruktur, observasi, Focus Group Discussion (FGD), dan dokumentasi terhadap arsip yang relevan. Subyek penelitian ini adalah orangtua, fasilitator dan kepala sekolah Taman Anak Salam. Untuk melakukan analisis data, penelitian ini mengikuti kerangka berpikir Miles dan Huberman. Dalam pandangan Miles dan Huberman aktivitas dalam analisis data kualitatif dilakukan secara interaktif dan berlangsung secara terus-menerus sampai tuntas, sehingga datanya jenuh. Aktivitas dalam analisis meliputi reduksi data (data redution), penyajian data (data display), serta penarikan kesimpulan dan verifikasi (conclusion drawing/verification). Analisa data dilakukan selama pengumpulan data dengan tahapan membuat ringkasan kontak, kode dan pengkodean, pola dan mengembangkan proposisi seperti dijelaskan dalam bagan berikut (Miles \& Huberman, 1992).

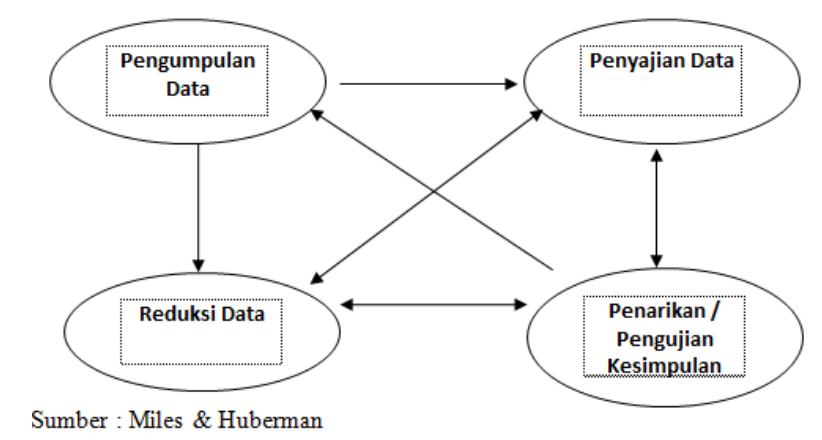

Gambar 1: Analisis Data Kualitatif Model Interaktif

\section{HASIL DAN PEMBAHASAN}

\section{Salam: Sekolah Berbasis Komunitas Lokal}

Sanggar Anak Alam (Salam) Nitiprayan Kasihan Bantul Yogyakarta, adalah lembaga pendidikan non-formal yang dirintis sejak tahun 1988 di Desa Lawen, Kecamatan Pandanarum, Banjarnegara. Salam menyelenggarakan pendidikan anak usia dini dan pendidikan kesetaraan yang meliputi: 1) Taman Bermain usia 2-4 tahun, 2) Taman Anak (TA) usia 4-6 tahun, 3) Sekolah Dasar (usia 6 tahun ke atas), 4) Sekolah Menengah Pertama, 5) Sekolah Menengah Atas.

Proses belajar di Salam menunjukkan jalinan interaksi antara sekolah, keluarga dan masyarakata untuk menyelenggarakan pendidikan. Salam membawa semangat untuk menumbuhkan rasa solidaritas dan memberikan kesempatan belajar yang sama bagi setiap orang, meski terdapat perbedaan latar belakang sosial, budaya, agama maupun ekonomi. Di Salam belajar merupakan gerakan untuk menemukan nilai-nilai serta pemahaman hidup yang lebih baik. 


\section{Taman Anak Bercerita di Salam}

Taman Anak adalah unit pendidikan di Salam yang khusus menyelenggarakan pendidikan untuk anak usia dini. Kelompok ini diperuntukkan untuk anak dengan usia 2-4 tahun. Kegiatan pembelajarannya dilaksanakan mulai hari Senin sampai dengan hari Jumat mulai pukul 09.00 - 11.30 WIB. Fokus utama kegiatan pembelajaran di kelompok ini adalah bermain dan bereksplorasi. Jumlah peserta didiknya dibatasi hanya berjumlah 25 anak, dengan jumlah fasilitator tetap 3 dan ditambah 3 relawan. Relawan ini biasanya adalah mahasiswa yang sedang melakukan kegiatan akademis seperti menyelesaikan skripsi maupun magang. Kegiatan belajar di Salam didukung oleh berbagai kegiatan berupa Home Visit, Minitrip, Cooking Class dan pasar Senin Legi yang melibatkan orangtua.

Ketika Taman Anak Bercerita digagas, tujuannya untuk memberikan ruang merdeka sekaligus mendokumentasikan karya besar para siswa. Anak dipersilahkan mengungkap ide-idenya melalui lukisan. Orang tua diberi tugas untuk menuliskan gagasan mereka yang diungkapkan dalam bahasa gambar (Yuri, 2019).

Kumpulan cerita yang diberi judul Taman Anak Bercerita berisi hasil gambar anak yang kemudian diceritakan kepada orangtuanya Tugas para orang tua adalah menuliskan apa yang di ceritakan oleh anaknya. Lalu semua cerita dikumpulkan menjadi sebuah buku yang diberi nama Taman Anak Bercerita. Hasil gambar tangan siswa Taman Anak Salam menggambarkan imajinasi mereka dan diluncurkan bertepatan dengan 'Bulan Presentasi Salam yang diadakan selama satu bulan lamanya. Proses pembelajaran tersebut dapat dilihat pada skema dibawah ini.

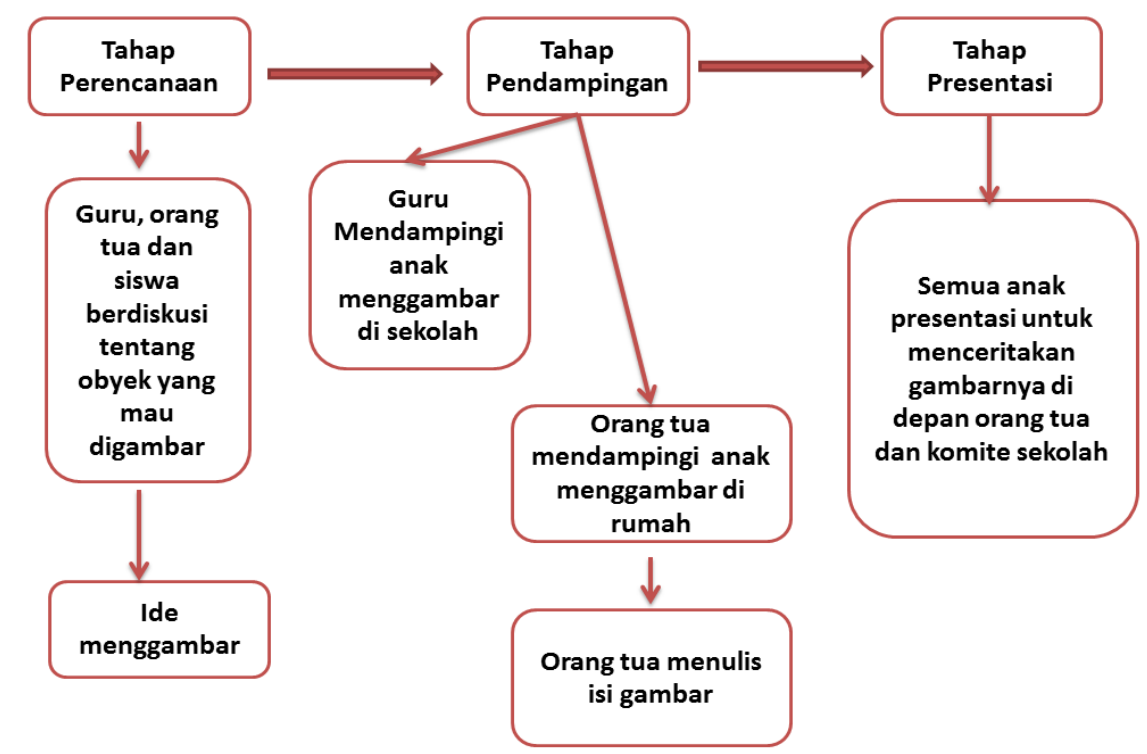

Sumber: Dokumentasi Salam

\section{Gambar 2 Daur Belajar di Salam}

Pada saat launching buku Taman Anak Bercerita ini, semua anak bergiliran maju ke depan untuk menceritakan lukisannya. Buku ini tidak bisa ditemukan di Gramedia atau toko buku. Jika ingin memilikinya, buku ini hanya ada di Salam. Acara ini dihadiri oleh orang tua, fasilitator dan komite sekolah dan anak bersemangat. Contohnya Dydy. Dydy menceritakan ayahnya yang sedang memancing ikan. Sementara teman-teman Dydy juga menceritakan gambarnya, meski ada yang masih malu-malu. Beberapa anak lainnya menunjukkan bakatnya seperti menyanyi dan menari. 


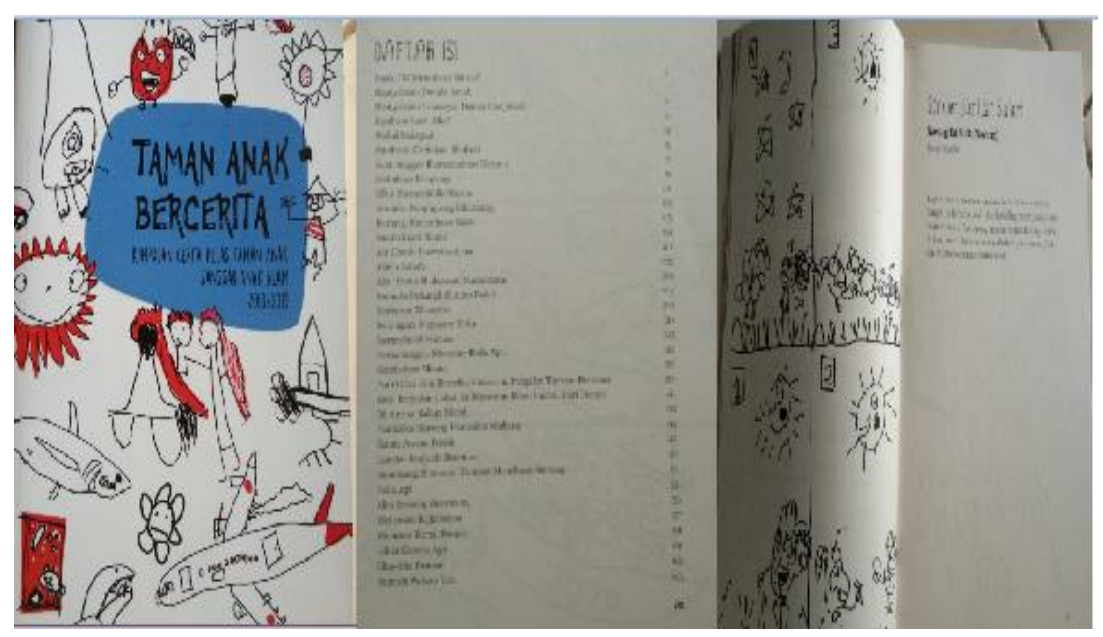

Gambar 3: Buku Taman Anak Bercerita

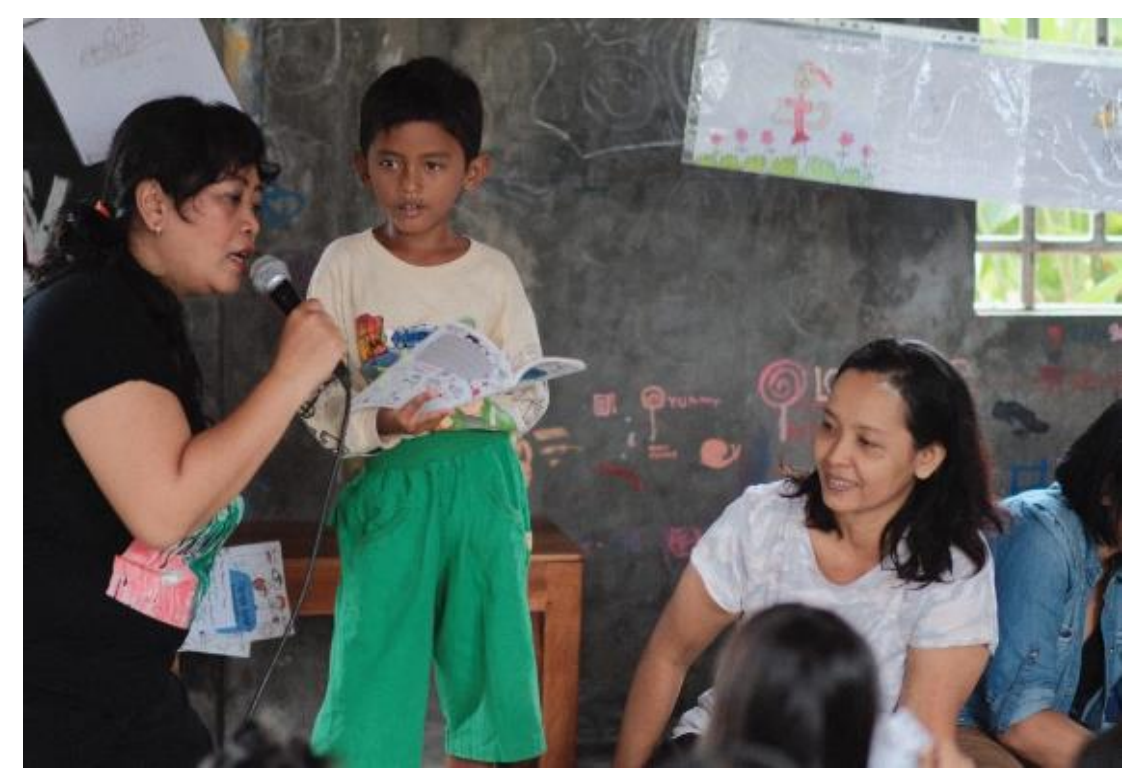

Gambar 4: Presentasi Siswa di Kelas

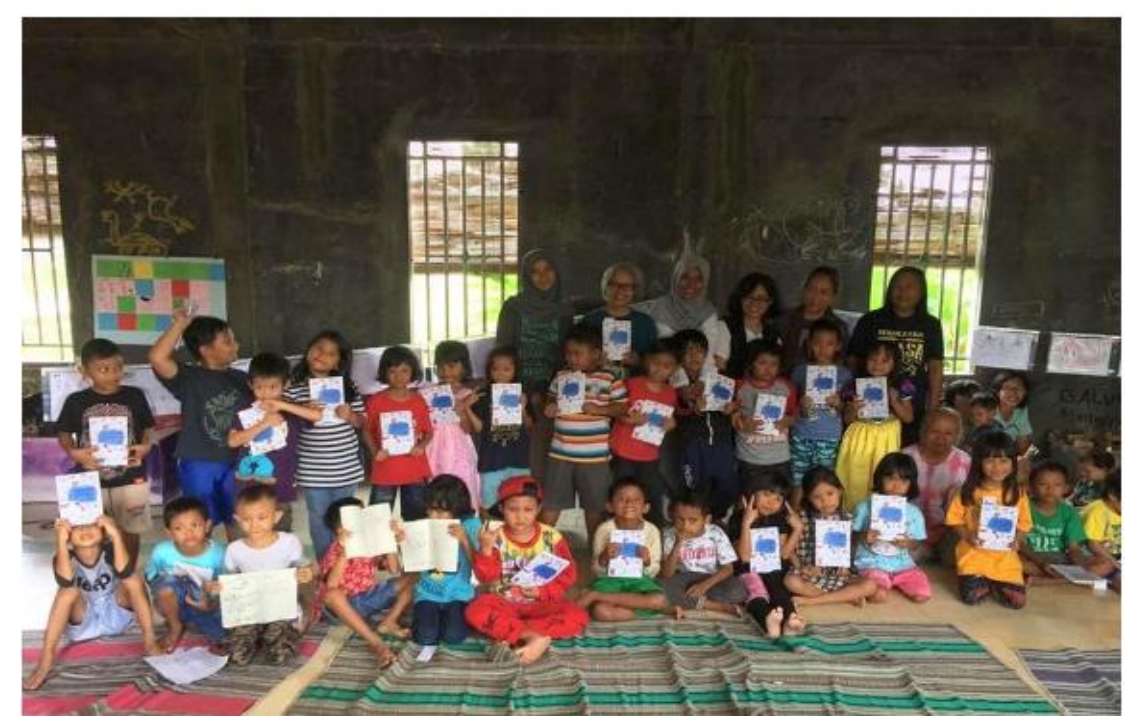

Gambar 5: Foto Bersama setelah usai presentasi 
Salam menjelma sebagai Sekolah Keluarga (family school) dan menjadi bagian dari masyarakat) serta bersifat life centered. Bagi Coleman, Salam telah mendesain keterlibatan orang tua dengan menciptakan komunikasi intens antara anak dan orang tua menjadi modal sosial yang menunjang kesuksesan anak dalam pendidikan (Coleman, 1988). Dalam konteks ini, Salam mengambil posisi menjalankan proses pendidikan yang berintikan pada kepentingan lokal (keluarga), tanpa mengesampingkan kepentingan lain yang melingkupinya yaitu kepentingan nasional sesuai amanat UUD 45.

Pendapat Murray menguatkan bahwa anak menjadi 'siap' dalam keberhasilan akademis awal ketika orang tua dan gurunya mendukung (Murray \& Harrison, 2011). Anak mendapatkan dukung positif melalui kerja kolaboratif yang menguntungkan orang tua dan anak (Franklin, 2018). Proses ini menegaskan bahwa anak akan mandiri, jika orang tua ikut membantu pekerjaan rumah anak melalui kolaborasi yang kuat dan sehat dan tidak menciptakan ketergantungan. Lingkungan keaksaraan yang diciptakan di rumah mendukung dan meningkatkan aspek literasi lisan dan tulisan dan menjadi landasan penting untuk mengantarkan anak pada lingkungan sekolah (Terrel, Pamela, Watson, \& Maggie, 2018).

Taman Anak Bercerita menunjukkan bahwa Salam adalah lembaga pendidikan yang mampu memberikan layanan pembelajaran akademik kepada masyarakat sebagai pedagogi yang efektif bagi pendidikan anak usia dini (Jones, 2017). Kondisi ini mendorong guru menggunakan berbagai sumber pengetahuan yang berfungsi dalam proses pembelajaran keaksaraan pada anak usia dini (Schachter R. E., 2017). Informasi orang tua tentang gaya belajar anak, pengetahuan yang diminati anak dan tujuan belajar bagi anak memudahkan guru menjalani proses pembelajaran lebih profesional. Kegiatan ini terbukti efektif memenuhi kebutuhan anak usia dini tentang kontek sosial dan konten keaksaraan awal. Pengaruh panjang intervensi kegiatan Taman Anak Bercerita membawa keuntungan yang lebih besar dalam penguasaan bahasa dan aksara.

Hal yang juga bisa dijelaskan dengan hadirnya Taman Anak Bercerita adalah parenting. Selama ini parenting dikenal hanya sebatas program yang dilaksanakan setiap semester pada saat penerimaan hasil evaluasi anak dengan mengundang pemateri yang terbatas pada pembahasan aspek psikologis dan kesehatan anak. Kehadiran buku ini, menjelaskan parenting sebagai bentuk keterlibatan orang tua pada proses pembelajaran secara sosial, psikologi dan kesehatan anak. Peran sekolah adalah memberikan ruang berkarya dan memberikan penghargaan kepada proses pembelajaran yang sedang berlangsung. Keterlibatan sekolah meningkatkan rasa aman, menginternalisasi nilai-nilai pendidikan dan memotivasi orang tua dan siswa untuk selalu belajar (Baker \& Hoerger, 2012).

Produksi masa kecil sebagai bentuk reformasi sekolah menghindari sebuah "bencana" mentalitas pada anak usia dini yang tidak percaya untuk menggoreskan idenya (Baker B. , 1998). Buku Taman Anak Bercerita menepis bahwa ketika menggambar anak hanya diberi kesempatan mewarnai gambar yang sudah disediakan dan ditambah dengan instruksi tidak boleh keluar garis ketika mewarnai. Bahkan soal warnapun sudah diatur sesuai dengan kehendak orang dewasa. Hasilnya? Bagus menurut kacamata orang dewasa. Bagus secara tampilan, namun kering makna. Sementara bagi anak, teknik-teknik itu belum tentu tepat. Ketika sebuah karya anak di mata orang dewasa tampak jelek, tapi bagi anak menjadi sarat dengan makna bahkan cita-cita. Menurut Foucault, Taman Anak Bercerita adalah bentuk kekuasaan yang bersifat divergen (menyebar) yang bersifat produktif dan kreatif (Martono, 2018). Kekuasaan ini lahir dari interaksi antara orang tua, guru dan siswa yang berfungsi untuk mempengaruhi praktik pendidikan dan bersifat dinamis. 
Adapun tiga wujud interaksi orang tua, fasilitator dan siswa di Kelompok Bermain Salam meliputi:

1. Kerjasama dalam menjalin komunikasi

Prinsip Salam adalah menciptakan kehidupan belajar yang merdeka dimana seluruh proses pendidikan dibangun atas dasar kebutuhan dan kesepakatan bersama seluruh warga belajar. Sebelum orang tua menyekolahkan anaknya di Salam, mereka diminta untuk membuat kesepakatan dengan pihak Salam mengenai pandangan dan metode pembelajaran yang ada di Salam.

2. Kerjasama dalam memberi dukungan

Dukungan dan kerjasama antar komponen komunitas di Salam berjalan baik. Salam membentuk Forum Orang Tua Salam (ForSalam) sebagai ruang diskusi dan koordinasi sehingga semua orang tua supaya terlibat aktif. Forum yang dikelola orang tua ini menjadi tempat diskusi dan mengontrol anak. Dukungan yang diberikan diantara orangtua berupa materi, tenaga ide maupun gagasan terhadap persoalan belajar siswa. Kondisi demikian menjadikan keluarga memperoleh pemahaman bersama tentang proses belajar yang dilakukan oleh anak-anaknya.

3. Kerjasama dalam memberi keteladanan

Keteladanan yang ditekankan di Salam dapat dilihat ketika seluruh komunitas belajar secara langsung maupun tidak langsung dalam bertindak dan berfikir. Meskipun pelajaran agama di Salam diserahkan kepada keluarga, fasilitator di Salam mengajarkan menghargai setiap pemeluk agama yang berbeda seperti berdoa, mengucapkan terima kasih kepada teman, fasilitator dan Tuhan YME. Pada saat pembelajaran sedang berlangsung setiap siswa diajarkan sikap minta maaf dan saling menghargai.

Hubungan yang berkualitas dan bersifat efektif dibangun untuk menjalin kerjasama antara orang tua dan sekolah yang bertujuan membangun komunitas belajar. Melalui proses ini siswa dan orangtua mendapatkan layanan pendidikan di sekolah untuk bereksplorasi yang didampingi oleh fasilitator. Dengan demikian peran keluarga sebagai pendidik utama tidak kehilangan fungsi sosialnya.

Salam menciptakan sekolah keluarga dengan mepertahankan hubungan antara keluarga dan lembaga pendidikan dalam pembentukan karakter seperti yang dinyatakan Lickona bahwa (Lickona, 2013): 1) keluarga adalah pihak pertama dan paling penting dalam mempengaruhi karakter anak dan 2) tugas sekolah adalah memperkuat nilai karakter positif yang sudah diajarkan di rumah, menjadi dalil setiap kegiatan pembelajaran di Salam.

\section{SIMPULAN}

Taman Anak Bercerita adalah produksi literasi masa kecil yang mampu mendorong percepatan perkembangan bahasa bagi anak usia dini. Hal ini dapat terwujud jika parenting sebagai bentuk keterlibatan orang tua pada proses pembelajaran menjadi modal sosial dalam pengembangan pendidikan. Modal sosial tersebut berhubungan dengan kerjasama keluarga, sekolah dan siswa dalam menjalin komunikasi, memberi dukungan serta keteladanan dari orang tua dan fasilitator untuk menciptakan lingkungan belajar.

\section{UCAPAN TERIMAKASIH}

Ucapan terima kasih peneliti kepada penggagas Salam yang telah memberikan pengetahuan tentang hakikat pendidikan yang humanis.

\section{DAFTAR PUSTAKA}

Baker, B. (1998). Childhood in the Emergence and Spread of U>S. Public Schools. In T. S. Popkewitz, Foucault's Challenge: Discourse, Knowledge, and Power in Education (pp. 117143). NY and LOndon: Teachers College, Columbia University.

Baker, C. N., \& Hoerger, M. (2012). Parental child-rearing strategies influence self-regulation, socio-emotional adjustment, and psychopathology in early adulthood: Evidence from a retrospective cohort study. Personality and Individual Differences, 800-805. 
Barton, D. (2012). Participation, deliberate learning and discourses of learning online. Language and Education, 139-150.

Coleman, J. (1988). Social Capital in the Creation of Human Capital. The American Journal of Sociology, 95-120.

Direktorat Jenderal, M. (2009). Penyelenggaraan Pendidikan Taman Kanak-Kanak. Jakarta: Departemen Pendidikan Nasional.

Franklin, D. (2018). Helping Your Child with Language-Base Learning Disabilities. Oakland, CA: New Harbinger Publications.

Jones, I. (2017). Integrarting Service Learning into Early Childhood Teacher Education: A Theoritical Perspective. In K. L. Heider, Service Learning as Pedagogy in Eray Childhood Education (pp. 1-14). Switzerland: Springer International Publishing.

Koch, H., \& Sporer, N. (2017). Student Improve in Reading Comprehension by Learning How to Teach Reading Strategies. An Evidence-based Approach for Teacher Education. Psychology Learning \& Teaching, 1-15.

Lickona, T. (2013). Character Matter: How to Kelp Our Children Develop Good Judgmen, Integrity, and Other Essentia Virtues (terjemahan). Jakarta: PT Bumi Aksara.

Martono, N. (2018, May). ResearchGate. Retrieved Januari 12, 2020, from Dominasi Kekuasaan dalam Pendidikan: Tesis Bourdieu dan Foucault tentang Pendidikan: https://www.researchgate.net/publication/325119775_Dominasi _Kekuasaan_dalam_Pendidikan_Tesis_Bourdieu_dan_Foucault_tentang_Pendidikan

McLachlan, C. J., \& Arrow , A. W. (2017). Literacy in the Early Years: Reflections on International Research and Practice. Singapore: Springer.

Miles, M. B., \& Huberman, A. M. (1992). Analisis Data Kualitatif. Jakarta: UI-Press.

Murray, E., \& Harrison, L. J. (2011). The influnence of being ready to learn on children's eraly scholl literacy and numeracy achivement. Educational Psychology, 529-545.

Schachter, R. E. (2017). Early Childhood Teachers' Pedagogical Reasoning About How Children Learn During Language and Literacy Instruction. International Journal of Early Childhood, 95-111.

Schachter, R. E. (2017). Early Childhood Teachers' Pedagogical Reasoning About How Children Learn During Language and Literacy Instruction. International Journal of Early Childhood, 95-111.

Sheridan, S. M., Knoche, L. L., \& White, A. S. (2019). Family-School Parthnership in Early Childhood: Exemplars of Evidence-Based Interventions. In S. B. Sheldon, \& T. A. Turner-Vorbeck, The Wiley Handbook of Family, School and Community Relationship in Education (pp. 183-202). John WIley \& Sons, Inc.

Teepe, R. C., Molenaar, I., Oostdam, R., Fukkink, R., \& Verhoeven, L. (2019). Helping parents enhance vocabulary development in preschool children: Effect of a family literacy program. Early Childhood Research Quarterly , 226-236.

Terrel, Pamela, Watson, \& Maggie. (2018). Laying a Firm Foundation: Embedding EvidenceBased Emergent Literacy Practices Into Early Intervention and Preschool Environments. Language Speech and Hearing Services in Schools, 148-164.

Ulfah, M. (2020). Pendekatan Holistik Integratif Berbasis Penguatan Keluarga. Jurnal Obsesi, 10-19.

Yeo, L. S., Ong, W. W., \& Ng, C. M. (2014). The Home Literacy Environment and Preschool Chlidren's Reading Skills and Interest. Early Education and Development, 791-814.

Yuri, A. (2019). Taman Anak Bercerita: Kumpulan Cerita Kelas Taman Anak Sanggar Anak Alam. Yogyakarta: Salam Books. 